\title{
Serangga Pengunjung Bunga yang Berpotensi sebagai Vektor Penyakit Darah pada Tanaman Pisang di Kabupaten Sigli, Banda Aceh
}

\author{
Betty Sahetapy ${ }^{1 *}$, Nina Maryana ${ }^{2}$, Syafrida Manuwoto², dan Kikin H. Mutaqin ${ }^{2}$ \\ ${ }^{1}$ Fakultas Pertanian Universitas Pattimura \\ Jln. Ir. M. Putuhena, Poka Ambon 97233 \\ ${ }^{2}$ Fakultas Pertanian, Institut Pertanian Bogor \\ *Alamat korespondensi: bettysahetapy@gmail.com
}

\begin{abstract}
Flower visitor insects as potential vectors of blood disease in banana plant in Sigli District, Banda Aceh
\end{abstract}

Blood disease of banana is caused by blood disease bacterium (BDB). The bacterium is suspected to be transmitted through infected seedlings, trimming equipments, soil swept away by water, root contacts as well as insects visiting banana flowers. This study aimed to determine the flower visitor insects which has the potential as vectors in the spread of blood diseases in banana plants. This study started by collecting insects in Padang Tiji Subdistrict, Sigli Regency, Banda Aceh Province. This location was endemic area of banana blood disease. The identification of insects was conducted at Insect Biosystematics Laboratory, while isolation and identification of BDB was conducted at Plant Bacteriology Laboratory, Department of Plant Protection, Faculty of Agriculture, Bogor Agricultural University. The isolated bacteria were confimed through Gram, hypersensitivity and pathogenicity tests. The Results showed that insects found in banana growing area Capah Paloh 1, Capah Paloh 2, Simpang Betung 1, Simpang Betung 2 and Pante Cermin Vilages were belongs to Diptera and Hymenoptera Orders. Drosophilidae (Diptera) are found predominantly among these insects. BDB is successfully isolated from whole insect body belongs to Diptera order (Drosophilidae, Tephritidae and Muscidae). This result showed that those insects seemed to be potensial as vector of BDB.

Keywords: Blood disease bacterium, Banana, Insects

\begin{abstract}
ABSTRAK
Penyakit darah disebabkan oleh blood disease bacterium (BDB). Bakteri diduga dapat ditularkan melalui bibit yang terinfeksi, alat pertanian, tanah yang terbawa air, kontak akar dan serangga pengunjung bunga pisang. Penelitian ini bertujuan untuk mengetahui serangga pengunjung bunga yang berpotensi sebagai vektor dalam penyebaran penyakit darah pada tanaman pisang. Penelitian diawali dengan pengumpulan sampel serangga di Kecamatan Padang Tiji, Kabupaten Sigli, Propinsi Banda Aceh. Lokasi ini merupakan area endemik penyakit darah pisang. Identifikasi serangga dilakukan di Laboratorium Biosistematika Serangga, sedangkan isolasi dan identifikasi BDB dilaksanakan di Laboratorium Bakteriologi Tumbuhan, Departemen Proteksi Tanaman, Fakultas Pertanian, Institut Pertanian Bogor. Bakteri yang diisolasi dikonfirmasi dengan uji Gram, hipersensitif dan patogenisitas. Hasil penelitian menunjukkan bahwa serangga yang ditemukan di area pertanaman pisang Desa Capah Paloh 1, Capah Paloh 2, Simpang Betung 1, Simpang Betung 2 dan Pante Cermin adalah tergolong dalam ordo Diptera dan Hymenoptera. Drosophilidae (Diptera) ditemukan lebih dominan di antara serangga-serangga tersebut. BDB berhasil diisolasi dari seluruh tubuh serangga ordo Diptera (Drosophilidae, Tephritidae dan Muscidae) sehingga membuktikan bahwa serangga-serangga ini berpotensi sebagai vektor BDB.
\end{abstract}

Kata Kunci: Blood disease bacterium, Pisang, Serangga 


\section{PENDAHULUAN}

Pisang merupakan komoditas buah yang sangat potensial dikembangkan untuk menunjang ketahanan pangan. Hal ini karena pisang memiliki keunggulan yang dibutuhkan, nutrisi, pelengkap, produktivitas dan kemampuan untuk mengatasi tekanan lingkungan sekitarnya untuk bertahan hidup. Produksi pisang di Indonesia menduduki tempat kelima dunia dengan besaran 3,6 juta ton atau $5 \%$ dari produksi dunia. Tingkat produktivitas pisang juga sangat tinggi dibandingkan sumber karbohidrat lainnya, sehingga dapat digunakan sebagai bahan pangan alternatif pengganti beras khususnya di daerah rawan pangan (Departemen Pertanian, 2012). Pisang memberikan kontribusi terhadap produksi buah nasional yang mencapai $34 \%$ yaitu 6.189 .052 ton dari 16.348 .456 ton produksi buah nasional. Sebaran daerah produksi pisang hampir di seluruh wilayah di Indonesia, dengan sebaran produksi tertinggi berada di Pulau Jawa, Jawa Barat, Jawa Timur dan Jawa Tengah yaitu sebesar 5.108.377 ton atau $63,7 \%$ dari total produksi pisang nasional, sedangkan di daerah lainnya seperti Lampung, Sumatera Utara dan Sumatera Selatan sebesar 940.390 ton atau 19,3\%, Sulawesi Selatan, Sulawesi Tengah dan Sulawesi Utara sebesar 6\%, sisanya dari Nusa Tenggara, Bali dan Kalimantan (Badan Pusat Statistik Indonesia, 2012).

Walaupun begitu, di Indonesia tanaman pisang ditanam dengan input produksi dan perhatian yang minim. Kondisi inilah yang menyebabkan usaha untuk meningkatkan produksi tanaman pisang menjadi lebih sulit. Padahal tanaman ini dapat tumbuh di berbagai tempat, baik di pekarangan sekitar rumah maupun di lahan-lahan sawah (Subandiyah et al., 2005). Selain budidayanya yang kurang baik, hama dan penyakit tanaman juga menjadi kendala tersendiri dalam usaha meningkatkan produksi tanaman pisang. Salah satu patogen penting pada tanaman pisang adalah Ralstonia solanacearum (blood disease bacterium, BDB) penyebab penyakit darah yang menempati urutan pertama dalam daftar prioritas penyakit tanaman pisang di Indonesia dan bersifat mematikan dengan menginfeksi jaringan pembuluh secara sistemik (Eden-Green 1992). Perkembangan dan penyebaran penyakit ini tergolong sangat cepat. Penyebaran geografis penyakit ini di Indonesia sekitar $100 \mathrm{~km}$ per tahun (Eden-Green 1994).

Cahyaniati et al. (1997) melaporkan bahwa pada bulan Mei 1993 penyakit ini telah menyebar di Kabupaten Lampung Selatan dengan luas areal yang terserang 13,18 Ha dan meningkat pada bulan Juni tahun 1993 menjadi 963,38 Ha. Intensitas serangan BDB tertinggi terjadi di propinsi Lampung yaitu seluas \pm 1800 Ha. Hal ini terjadi karena sebagian besar kebun telah terinfeksi penyakit dan umumnya varietas yang di tanam rentan terhadap penyakit tersebut. Insidensi penyakit darah pisang dalam kebun di Kabupaten Minahasa Utara bervariasi dari suatu kecamatan ke kecamatan lainnya. Rata-rata insidensi yakni 9,57\% dengan insidensi tertinggi di Kecamatan Likupang Barat (10,64\%), diikuti oleh Kecamatan Talawaan $(9,19 \%)$ dan Kecamatan Wori (8,88\%) (Montong dkk. 2013). Sementara itu, hasil pengamatan langsung di lapangan serangan BDB di Kabupaten Sigli, Propinsi Banda Aceh, kerusakan mencapai $100 \%$ karena semua perkebunan pisang milik rakyat tidak satupun bisa dipanen. Menurut petani setempat serangan penyakit ini dimulai tahun 2008 dan mencapai puncaknya di tahun 2011. Pada tahun 2011 penyakit BDB mulai menyebar sampai pertanaman pisang yang berada di pekarangan penduduk. Kejadian penyakit darah dan penyebaran di lapangan sangat tinggi. Hal ini disebabkan belum adanya tanaman pisang yang tahan terhadap penyakit ini dan tingginya potensi penularan patogen.

Dilaporkan bahwa kehilangan hasil secara ekstrim karena BDB ditemukan pada kebun-kebun yang ditanami kultivar-kultivar pisang dengan kelompok genetik $\mathrm{ABB}$, terutama kultivar pisang sepatu (kepok), sebab insidensi penyakit mencapai lebih dari 80\% (Hadiwiyono, 2011). Kehilangan hasil karena serangan BDB tidak hanya terjadi di pertanaman tradisional yang merupakan tanaman campuran, tetapi juga di pertanaman komersial yang monokultur. Penyebaran penyakit ini dapat terjadi melalui bibit (anakan pisang), tanah, alat-alat pertanian dan serangga. Menurut Hayward (2006) epidemi penyakit darah dapat terjadi karena ketersediaan inang rentan (pisang kepok) secara terus menerus, karena patogen $R$. solanacearum sudah terdapat dalam tanah (soil-borne). Selain itu terdapat jenis serangga yang hidup pada permukaan tanah (insect-borne) yang dapat menyebarkan patogen dalam jarak pendek atau jauh. Bahkan patogen dapat terbawa melalui alat pertanian, berupa parang, cangkul, sekop, dan lain lain. $R$. solanacearum di dalam jaringan tanaman hidup tidak memproduksi sel-sel tahan terhadap kekeringan dan kemungkinan mereka bertahan pada ooze yang menempel pada tubuh serangga (Hayward, 2006). Di Uganda, serangga-serangga yang berperan sebagai carrier bakteri penyebab layu pisang yaitu Plebeinadenoiti (Apidae), Clorofidae, 
Drosophilidae, Apis melifera (Apidae), dan Apidae lainnya (Tinzaara et al., 2006).

Ada beberapa jenis serangga yang berpotensi sebagai agen penyebar penyakit layu bakteri antara lain serangga dari ordo Hymenoptera (Apidae), Diptera (Chloropidae, Sciaridae, Sarcophagidae, Anthomyiidae, Platypezidae, Tephritidae, Drosophilidae, Muscidae, Syrphidae dan Culicidae), Lepidoptera (Coleophoridae) dan Blattodea (Blattidae) (Leiwakabessy 2003; Suspendy 2001; Supriadi 2005). Sementara itu, propagul patogen layu bakteri dapat menempel dan termakan oleh Trigona sp., Apis dorsata, Apis cerana, Erionata thrax, Oecophylla smaragdina, dan Nezara viridula (Mairawita dkk., 2012). Informasi yang diperoleh Penulis, di Aceh sejak tahun 2008 sudah terjadi serangan penyakit darah pisang secara besar-besaran dan hampir semua lahan milik petani tidak bisa dipanen lagi pada waktu itu. Laporan mengenai kerugian akibat serangan penyakit darah di daerah Aceh secara khusus belum ada. Untuk mengetahui serangga pengunjung bunga yang berpotensi sebagai vektor dalam penyebaran penyakit darah pada tanaman pisang di Aceh maka dilakukan penelitian ini yang meliputi koleksi dan identifikasi serangga, serta isolasi BDB dari jenis-jenis serangga pengunjung bunga pisang.

\section{BAHAN DAN METODE}

\section{Tempat dan Waktu Penelitian}

Pengambilan sampel serangga dilakukan di Desa Capah Paloh 1, Capah Paloh 2, Simpang Betung 1, Simpang Betung 2 dan Desa Pante Cermin yang berada di Kecamatan Padang Tiji, Kabupaten Sigli, Propinsi Banda Aceh. Desa-desa tersebut merupakan daerah endemik penyakit darah pisang. Identifikasi serangga dilakukan di Laboratorium Biosistematika Serangga, sedangkan isolasi, identifikasi BDB dilakukan di Laboratorium Bakteriologi Tumbuhan, Departemen Proteksi Tanaman, Fakultas Pertanian, Institut Pertanian Bogor.

\section{Pengambilan Sampel Serangga yang Berpotensi Sebagai Vektor BDB}

Koleksi serangga dilakukan dengan menggunakan perangkap lekat kuning (sticky yellow trap) dan jaring serangga (sweepnet). Pengambilan sampel dilakukan sekali dalam seminggu selama empat minggu pengamatan. Untuk keperluan identifikasi serangga, serangga yang tertangkap dimasukkan ke dalam botol berukuran 30 $\mathrm{ml}$ berisi alkohol 70\% sedangkan untuk keperluan isolasi bakteri, serangga dimasukkan dalam botol berisi air steril. Pemisahan ini bertujuan untuk memudahkan dalam mengisolasi bakteri penyebab penyakit darah pisang dari tubuh serangga. Setelah itu identifikasi serangga dilakukan dengan mengacu pada kunci yang disusun oleh McAlpine (1981), Colless (1996) dan Naumann (1996).

\section{Identifikasi BDB dari Isolat yang Dibuat dari Bagian Tubuh Serangga}

Isolasi dilakukan untuk melihat keberadaan bakteri penyebab penyakit darah pisang (BDB) di tubuh serangga dan dilakukan pada setiap jenis serangga yang tertangkap dengan menggunakan metode modifikasi isolasi penyakit darah menurut Cahyaniati et al. (1997). Isolasi BDB dari bagian luar (permukaan) tubuh serangga dilakukan dengan cara air pencucian tubuh serangga diambil sebanyak 100 $\mu \mathrm{l}$ dan ditambahkan dengan air steril sebanyak 900 $\mu \mathrm{l}$. Selanjutnya dilakukan pengenceran sebanyak lima tingkatan untuk mendapatkan bakteri yang tumbuh secara teratur pada media TZC. Pengamatan terhadap ciri-ciri koloni BDB dilakukan setelah biakan berumur 48-72 jam, selanjutnya diinkubasikan pada suhu $28^{\circ} \mathrm{C}$. Koloni bakteri yang sudah murni dipindahkan ke media SPA selama 1-2 hari pada suhu $28^{\circ} \mathrm{C}$ dan disimpan di dalam air steril.

Isolasi BDB dari bagian dalam tubuh serangga dilakukan sebagai berikut, jaringan tubuh serangga yang disimpan di dalam tabung plastik dilakukan desinfeksi dengan larutan natrium hipoklorit selama 5 menit, kemudian dibilas sebanyak 3-4 kali dengan air steril untuk menghilangkan sisa-sisa natrium hipoklorit. Jaringan tubuh serangga digerus hingga hancur dan ditambahkan air steril sebanyak $10 \mathrm{ml}$, kemudian diencerkan secara bertingkat sebanyak 5 kali. Selanjutnya suspensi ini diteteskan pada media TZC yang telah disiapkan. Pengamatan terhadap ciri-ciri koloni BDB dilakukan setelah biakan berumur 48-72 jam, selanjutnya diinkubasikan pada suhu $28^{\circ} \mathrm{C}$. Koloni bakteri yang sudah murni dipindahkan ke media SPA selama 1-2 hari pada suhu $28^{\circ} \mathrm{C}$ dan disimpan dalam air steril.

\section{Identifikasi Bakteri}

Identifikasi dilakukan untuk memastikan bahwa bakteri yang diisolasi dari tubuh serangga benar-benar BDB. Isolat yang diperoleh diamati karakteristiknya berdasarkan sifat morfologi koloni dan fisiologinya seperti yang diuraikan oleh EdenGreen dan Sastraatmadja (1990) dan CABI (2003). Selanjutnya dilakukan beberapa pengujian yaitu uji reaksi Gram, pengujian ini merupakan tahapan awal dalam mengidentifikasi suatu spesies bakteri yang 
belum diketahui. Pengujian dilakukan dengan menggunakan larutan $\mathrm{KOH} 3 \%$ dan jika di dalam pengujian ini ada reaksi (lengket) maka digolongkan dalam reaksi gram negatif. Sebaliknya jika tidak ada reaksi, maka bakteri tersebut bersifat gram positif. Kemudian uji reaksi hipersensitif untuk menentukan apakah isolat yang berhasil diisolasi tergolong patogen atau non patogen. Pengujian dilakukan dengan metode Lelliott dan Stead (1987). Suspensi bakteri diinjeksikan ke daun tembakau melalui daun sekunder. Isolat yang bersifat patogen akan menunjukkan gejala putih transparan, kematian jaringan daun (collapse) di sekitar tempat injeksi dalam kurun waktu 24-48 jam setelah injeksi, dan akhirnya jaringan daun mengering. Setelah itu dilakukan uji patogenisitas dengan metode inokulasi injeksi.

\section{HASIL DAN PEMBAHASAN}

\section{Jenis Serangga Pengunjung Bunga Pisang}

Serangga yang tertangkap dengan perangkap lekat kuning di Desa Capah Paloh 1, Capah Paloh 2, Simpang Betung 1, Simpang Betung 2 dan Pante Cermin adalah Ordo Diptera. Ciri khas ordo Diptera mempunyai sepasang sayap depan dan satu pasang sayap belakang berubah menjadi alat keseimbangan yang disebut halter. Famili serangga yang dominan adalah famili Drosophilidae dan famili lain yang cukup banyak tertangkap adalah famili Muscidae dan Tephritidae (Tabel 1). Banyaknya serangga yang tertangkap di kelima desa ini dipengaruhi oleh kondisi iklim dan cuaca pada saat dilakukan pemerangkapan. Cuaca mendung dan intensitas penyinaran yang rendah menyebabkan jumlah serangga yang mengunjungi bunga pisang akan berkurang. Suhu udara rata-rata berkisar 25,40$26,20^{\circ} \mathrm{C}$, RH 85-90\%, curah hujan 56,60-164,60 mm dan lama penyinaran 40,00-52,20\% (BPS, 2012). Menurut Chasanah (2010), suhu dan intensitas cahaya berpengaruh positif terhadap jumlah individu serangga, sedangkan kelembaban berpengaruh negatif. Selain faktor di atas umur bunga dan bau yang dikeluarkan juga berpengaruh terhadap ketertarikan serangga pengunjung bunga. Bradbury (2010) menyatakan bahwa seranggaserangga pengunjung bunga menghindari bungabunga lebih tua karena sudah tidak efisien sebagai sumber makanan dan juga tidak terjadi kunjungan secara berulang-ulang. Semua serangga pengunjung bunga pisang kepok sakit membawa sejumlah sel $R$. solanacearum filotipe IV lebih banyak daripada yang mengunjungi bunga pisang sehat. Serangga-serangga pengunjung bunga pisang kepok sehat membawa bakteri penyakit darah. Fakta ini membuktikan bahwa serangga-serangga ini telah mengunjungi bunga pisang sakit, kemudian melakukan foraging pada bunga sehat (Montong dkk., 2019). Penangkapan serangga dengan menggunakan perangkap lekat kuning (Tabel 1) lebih efektif dibandingkan dengan jaring serangga (Tabel 2). Perangkap lekat kuning dipasang terus menerus selama satu minggu sehingga peluang serangga untuk tertangkap cukup tinggi. Penangkapan dengan jaring serangga hanya dilakukan pada saat pengambilan sampel saja. Penggunaan warna kuning pada perangkap lekat bertujuan untuk menarik sebanyak mungkin serangga untuk berkunjung ke bunga pisang. Hal ini sesuai dengan Maryam dkk. (1997) yang melaporkan bahwa penangkapan serangga dengan perangkap lekat kuning pada bunga pisang diperoleh lebih banyak jenis serangga daripada perangkap penghisap (suction trap). Serangga yang tertangkap dengan jaring serangga jumlahnya relatif sedikit. Jaring serangga tidak bisa menjangkau serangga yang beraktivitas di sekitar bunga pisang karena pohon pisang kepok relatif tinggi.

\section{Serangga-serangga yang Berpotensi dalam Penyebaran Penyakit Darah Pisang}

Berdasarkan beberapa pengujian terhadap isolat BDB yang diperoleh dari permukaan tubuh serangga dan isolat dari bagian dalam tubuh serangga diperoleh hasil ada beberapa serangga berpotensi dalam penyebaran penyakit darah pisang (Tabel 3). Isolat BDB asal serangga yang diuji reaksi hipersensitif sebanyak 26 isolat dan 20 isolat yang memperlihatkan reaksi positif sedangkan 6 isolat menunjukkan reaksi negatif (non patogenik).

Serangga yang berpotensi sebagai vektor adalah dari ordo Diptera khususnya famili Drosophilidae, Tephritidae dan Muscidae (Gambar 1). Dikatakan berpotensi karena adanya bakteri BDB yang ditemukan di dalam tubuh pada ketiga famili tersebut dan memiliki virulensi yang tinggi, sedangkan serangga dari ordo lainnya, bakteri BDB ditemukan pada bagian luar tubuh serangga. Hal ini sesuai dengan pendapat Maryam dkk. (1997), yang menyatakan bahwa ordo Diptera (famili Drosophilidae) berpotensi sebagai vektor penyakit layu bakteri pada pisang kepok dan ambon jepang. 
Tabel 1. Serangga ordo Diptera pengunjung bunga pisang yang tertangkap perangkap lekat di desa contoh

\begin{tabular}{lccccc}
\hline \multirow{2}{*}{ Ordo Diptera } & \multicolumn{5}{c}{ Jumlah (individu) per desa } \\
\cline { 2 - 6 } & $\begin{array}{l}\text { Simpang } \\
\text { Betung } 1\end{array}$ & $\begin{array}{c}\text { Simpang } \\
\text { Betung 2 }\end{array}$ & $\begin{array}{c}\text { Capah } \\
\text { Paloh } 1\end{array}$ & $\begin{array}{c}\text { Capah } \\
\text { Paloh 2 }\end{array}$ & $\begin{array}{c}\text { Pante } \\
\text { Cermin }\end{array}$ \\
\hline Drosophilidae & 110 & 70 & 50 & 81 & 25 \\
Muscidae & 10 & 2 & 8 & 9 & 6 \\
Calliphoridae & 7 & 3 & 0 & 0 & 3 \\
Micropetidae & 8 & 0 & 0 & 0 & 8 \\
Rhicardiidae & 5 & 0 & 0 & 0 & 0 \\
Platypezidae & 0 & 15 & 0 & 0 & 0 \\
Cypselosomatidae & 0 & 5 & 0 & 0 & 0 \\
Tephritidae & 8 & 7 & 8 & 6 & 0 \\
Tethinidae & 0 & 0 & 5 & 0 & 0 \\
Dryomizydae & 0 & 0 & 0 & 5 & 0 \\
Milichiidae & 0 & 0 & 0 & 4 & 0 \\
Lauxaniidae & 0 & 0 & 0 & 3 & 0 \\
Canopidae & 0 & 0 & 0 & 0 & 4 \\
Phoridae & 0 & 0 & 0 & 0 & 2 \\
Sciomyzidae & 0 & 0 & 0 & 0 & 2 \\
Piophilidae & 0 & 0 & 0 & 0 & 4 \\
Neriidae & 0 & 0 & 0 & 4 & 0 \\
\hline
\end{tabular}

Tabel 2. Serangga oOrdo Hymenoptera yang tertangkap jaring serangga di desa contoh

\begin{tabular}{lccccc}
\hline \multirow{2}{*}{$\begin{array}{c}\text { Ordo } \\
\text { Hymenoptera }\end{array}$} & Simpang & Simpang & Capah & Capah & Pante \\
\cline { 2 - 6 } & Betung 1 & Betung 2 & Paloh 1 & Paloh 2 & Cermin \\
\hline Apidae & 2 & 0 & 0 & 0 & 0 \\
Vespidae & 0 & 3 & 0 & 0 & 0 \\
\hline
\end{tabular}
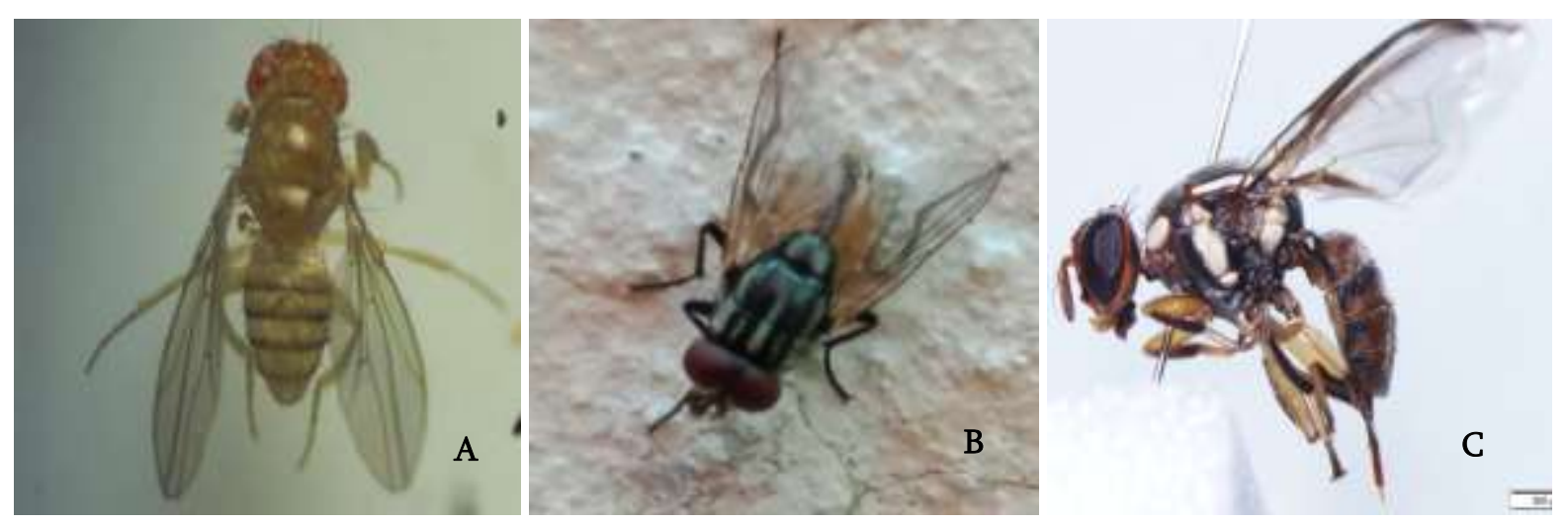

Gambar 1. Serangga pengunjung bunga pisang yang berpotensi sebagai vektor penyakit darah.

(A) Drosophilidae. (B) Tephritidae. (C) Muscidae.

\section{Karakterisasi Isolat BDB}

Karakter koloni isolat BDB yang ditunjukkan pada Gambar 2, diantaranya koloni tumbuh lambat, berbentuk bulat dengan ukuran kecil-kecil (0,5-3 $\mathrm{mm}$ ), non fluidal dan agak lengket (viscid). Bakteri bersifat Gram negatif, tidak berfluoresens pada media KBA, bersifat oksidatif, tidak menghidrolisis arginin, dan reaksi hipersensitifnya positif. Karakteristik ini sesuai dengan yang dikemukakan oleh Eden Green \& Sastraatmadja (1990), Baharuddin (1994), Supriadi (1999) dan CABI (2003). 
Tabel 3. Hasil uji Gram negatif, uji reaksi hipersensitif dan uji patogenisitas isolat bakteri

\begin{tabular}{lllcc}
\hline \multicolumn{1}{c}{ Ordo } & \multicolumn{1}{c}{ Asal Isolat } & \multicolumn{1}{c}{$\begin{array}{c}\text { Uji Gram } \\
\text { negatif }\end{array}$} & $\begin{array}{c}\text { Reaksi } \\
\text { hipersensitif }\end{array}$ & $\begin{array}{c}\text { Uji } \\
\text { patogenisitas }\end{array}$ \\
\hline Diptera & Muscidae (a) & Negatif & Positif & Positif \\
Diptera & Muscidae (b) & Negatif & Positif & Positif \\
Diptera & Calliphoridae (a) & Negatif & Positif & Negatif \\
Diptera & Micropetidae (a) & Negatif & Negatif & Negatif \\
Diptera & Micropetidae (b) & Negatif & Positif & Positif \\
Diptera & Drosophilidae (a) & Negatif & Positif & Positif \\
Diptera & Drosophilidae (b) & Negatif & Positif & Positif \\
Diptera & Cypselasomatidae (a) & Negatif & Positif & Positif \\
Hymenoptera & Apidae (b) & Negatif & Positif & Negatif \\
Hymenoptera & Vespidae (a) & Negatif & Negatif & Negatif \\
Hymenoptera & Vespidae (b) & Negatif & Negatif & Negatif \\
Diptera & Tephritidae(a) & Negatif & Positif & Positif \\
Diptera & Tephritidae (b) & Negatif & Positif & Positif \\
Diptera & Neridae (a) & Negatif & Negatif & Negatif \\
Diptera & Neridae (b) & Negatif & Positif & Positif \\
Diptera & Platypezidae (b) & Negatif & Positif & Positif \\
Diptera & Asilidae (a) & Negatif & Negatif & Negatif \\
Diptera & Bombyliidae (b) & Negatif & Positif & Negatif \\
Diptera & Phoridae (a) & Negatif & Positif & Positif \\
Diptera & Phoridae (b) & Negatif & Positif & Positif \\
\hline
\end{tabular}

Keterangan: (a) isolat yang berasal dari permukaan tubuh serangga (b) isolat yang berasal dari bagian dalam tubuh serangga
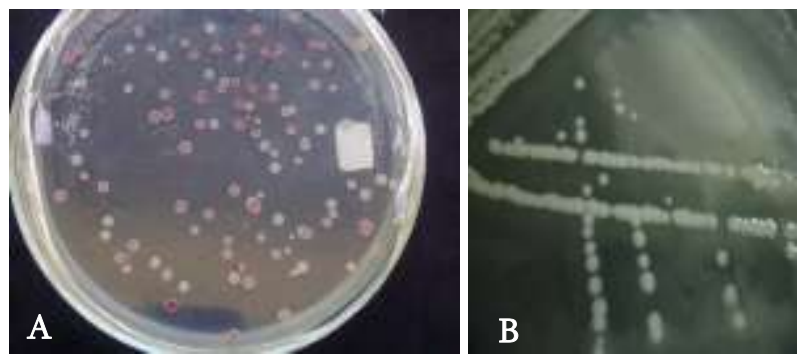

Gambar 2. Karakteristik bentuk koloni BDB yang diisolasi dari bagian tubuh serangga.

(A) Pada media TZC. (B) Pada media SPA.

Isolat-isolat $\mathrm{BDB}$ asal serangga ini sebelum diuji patogenisitas, dilakukan pengujian reaksi hipersensitif (Gambar 3). Hasil pengujian menunjukkan bahwa isolat yang diuji ada yang bereaksi positif dengan munculnya gejala hipersensitif pada daun tembakau berupa gejala nekrotik. Hasil pengujian patogenisitas isolat-isolat BDB terhadap tanaman pisang ternyata juga mampu menimbulkan gejala layu. Hasil ini membuktikan bahwa isolat yang diisolasi dari bagian tubuh

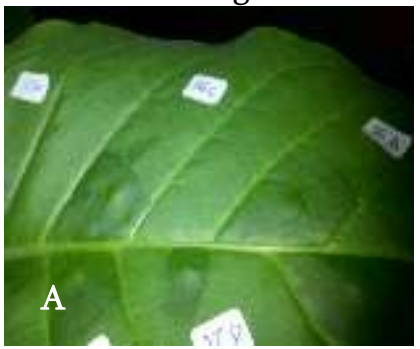

serangga baik pada permukaan tubuh maupun dari dalam tubuh serangga adalah penyebab penyakit darah. BDB merupakan bakteri yang menyerang pembuluh xylem tanaman pisang yang terletak pada batang pisang (true stem). Gejala layu pada tanaman pisang yang terserang BDB tampak karena adanya penyumbatan aliran air oleh extracellular polysaccharide (EPS) bakteri yang berada pada saluran xylem tanaman (Suharjo dkk., 2006).

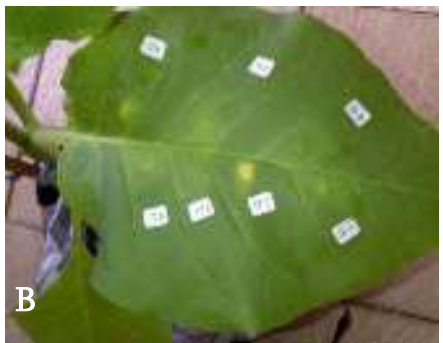

Gambar 3. Hasil uji hipersensitif. (A) Sesaat setelah disuntik. (B) Gejala yang muncul setelah 48 jam. 


\section{SIMPULAN}

Serangga-serangga yang tertangkap didominasi oleh ordo Diptera famili Drosophilidae dengan jumlah tangkapan yang paling banyak untuk kelima desa sampel dibandingkan dengan famili lainnya. Serangga ordo Diptera (Drosophilidae, Tephritidae dan Muscidae) berpotensi sebagai vektor penyakit darah pisang (BDB), penyebab penyakit ini ditemukan di dalam jaringan tubuh serangga.

\section{DAFTAR PUSTAKA}

Baharuddin. 1994. Pathological, Biochemical and Serelogical of Characterization of the Blood Disease Bacterium Affecting Banana and Plantain (Musa spp.) in Indonesia. [Disertasi]. Cuvillier. Gottingen.

BPS. 2012. Statistik Indonesia 2012, Jakarta. Biro Pusat Statistik. Tersedia online pada http//www.bps.go.id/. Diakses 23 Maret 2012.

Bradbury, K. 2010. Pollination for Vegetable Gardens. Available at https://extension. colostate.edu/topic-areas/insects/creatingpollinator-habitat-5-616/. Accessed 16 October 2018.

CABI. 2003. Crop Protection Compedium. Centre in Agricultural and Biological Institute [cdrom]. CABI Publish. London.

Chasanah, LR. 2010. Keanekaragaman dan Frekuensi Kunjungan Serangga Penyerbuk serta Efektivitasnya dalam Pembentukan Buah Hoya Multiflora Blume (Asclepiadaceae). [Tesis]. Pasca Sarjana Insitut Pertanian Bogor. Bogor.

Cahyaniati, CN Mortesen, and SB Mathur. 1997. Bacterial wilt of banana in Indonesia. Technical Bulletin Jakarta. Direktorat Perlindungan Tanaman.

Colless DH, McAlpin JK. 1996. Diptera. Dalam Commonwealth Sientific and Industrial Research Organisation (CSIRO) (Division of Entomology). The Insects of Australia.A text book for students and workers vol 2 . Melbourne (AU). Melbourne University Press. Hlm 717-786

Departemen Pertanian. 2012. Komoditas Unggulan. Direktorat Jenderal Hortikultura. Jakarta. Tersedia online pada hortikultura.pertanian.go.id. Diakses 23 Maret 2013.
Eden-Green, SJ, and AH Sastraatmadja. 1990. Blood disease bacterium present in Java. FAO Plant Protection Bulletin. 38: 49-90.

Eden-Green, SJ. 1992. Characteristics of Pseudomonas solanacearum and related bacteria from banana and plantain in South East Asia. In Pp. 51-57. Plant Pathogenic Bacteria (M Lemattre, S Freigoun, K Rudolph, JG Swings, Eds.). IRNA. Versailles.

Eden-Green, SJ. 1994. Banana Blood Disease. Musa Disease Fact Sheet No.3. 2p. INIBAP. Montpellier.

Hayward, AC. 2006. Bacterial wilt caused by Pseudomonas solanacearum, in Asia and Australia: An overview. In Pp. 15-24. Bacterial Wilt Disease in Asia and the South Pacific (GJ Persley, ed.). Australian Centre for International Agricultural Research Proceeding. Canberra.

Hadiwiyono, 2011. Blood bacterial wilt disease of banana: The distribution of pathogen in infected plant, symptoms, and potentiality of diseased tissues as source of infective inoculums. Nusantara Bioscience. 3(3): 112117.

Leiwakabessy, C. 2003. Potensi beberapa jenis serangga dalam penyebaran penyakit layu bakteri Ralstonia solanacearum Yabuchi et al. pada pisang di Lampung. J Pertanian Kepulauan. 2(2): 137-145.

Lelliott, RA, and DE Stead. 1987. Methodes for the Diagnosis of Bacterial Diseases of Plants. Blacwell Scientific Pub. Oxford.

Mairawita, T Habazar, A Hasyim, N Nazir, dan Suswati 2012. potensi serangga pengunjung bunga sebagai vektor penyakit darah bakteri (Ralstonia solanacearum Phylotipe IV) pada pisang di Sumatera Barat. Jurnal Entomologi Indonesia. 9(1): 38-47.

Maryam, Abn, O Tata Rasta, W Handayani, dan D Sihombing. 1997. Beberapa jenis serangga pengunjung bunga pisang yang diduga sebagai penular penyakit layu bakteri (Pseudomonas solanaceurum E.F. Smith). Prosiding Rapat Kerja Penyusunan Prioritas dan Desain Penelitian Hortikultura. Balai Penelitian dan Pengembangan Pertanian, Pusat Penelitian dan Pengembangan Hotikultura. Solok 17-19 Nopember 1994.

McAlpine, JF. 1981. Key to families-adults. In Pp. 89-124. Manual of Nearctic Diptera (JF McAlpine, BV Peterson, GE Shewell, HJ Teskey, JR Vockeroth, DM Wood, Eds.). 
Vol. 1. Monograph No.27. Biosystematics Research Institute Ottawa, Ontario.

Montong, VB, RTD Maramis, J Pelealu, dan CL Salaki. 2013. Insidensi penyakit darah pisang di Kabupaten Minahasa Utara. Prosiding Semnas dan Kongres XX Fitopalogi untuk Mendukung Kemandirian Pangan dan Ekonomi Bebasis IPTEK Ramah Lingkungan. Padang, 8-10 Oktober 2013.

Montong, VB, RTD Maramis, J Pelealu, dan CL Salaki. 2019. Serangga pengunjung bunga pisang kepok di Kabupaten Minahasa Selatan sebagai pembawa Ralstonia solanacearum filotipe IV (penyebab penyakit darah pisang). Jurnal Enfit. 1(1): 17-28.

Naumann, ID. 1996. Lepidoptera. In Pp. 916-1000. The Insects of Australia: A Text Book for Students and Workers. Commonwealth Scientific and Industrial Research Organisation (CSIRO)-Division of Entomology. $2^{\text {nd }}$ Ed. Melbourne University Press. Melbourne.

Subandiyah, S, S Indarti, T Harjaka, SNH Utami, C Sumardiyono, and Mulyadi. 2005. Bacterial wilt disease complex of banana Indonesia. In Pp. 415-422. Bacterial Wilt Disease and the Ralstonia solanacearum Species Complex (C Allen, P Prior, AC Hayward, Eds.). APS Press. St. Paul.
Suharjo, R, E Martono, dan S Subandiyah. 2006. Potensi Erionota thrax sebagai agen penyebar patogen penyebab penyakit layu bakteri pada tanaman pisang (blood disease bacterium). J. HPT Tropika. 6(2): 100-106.

Supriadi. 1999. Karakterisasi kultur dan patogenisitas isolat Pseudomonas celebensis penyebab penyakit darah pada tanaman pisang. J Hortikultura. 9(2): 129-136.

Supriadi. 2005. Present status of blood disease in Indonesia. In Pp. 395-404. Bacterial Wilt Disease and the Ralstonia solanacearum Species Complex (C Allen, P Prior, AC Hayward, Eds.). APS Press. St. Paul.

Suspendy, R. 2001. Potensi beberapa jenis serangga dalam penyebaran penyakit layu bakteri (Ralstonia solanacearum) pada tanaman pisang. Prosiding Perspektif Pembangunan Pertanian dan Kehutanan Tahun 2001 (Buku II). Balai Penelitian dan Pengembangan Pertanian.

Tinzaara, W, CS Gold, F Ssekiwoko, W Tushemereirwe, R Bandyopadhyay, A Abera, and SJ Eden-Green. 2006. Role of insects in the transmission of banana bacterial wilt. African Crop Science Journal. 14(2): 105-110. 